\title{
Results and Interpretation of the WFRD ELS Distillation
}

\section{Down-Select Test Data}

\author{
Lance Delzeit ${ }^{1}$ and Michael Flynn ${ }^{2}$ \\ Ames Research Center, Moffett Field, California, 94035 \\ Layne Carter ${ }^{3}$, and David Long ${ }^{4}$ \\ Marshall Space Flight Center, Huntsville, Alabama, 35812
}

Testing of the Wiped-film Rotating-disk (WFRD) evaporator was conducted in support of the Exploration Life Support Distillation Down-Select Test. The WFRD was constructed at NASA Ames Research Center (ARC) and tested at NASA Marshall Space Flight Center (MSFC). The WFRD was delivered to MSFC in September 2009, and testing of solution \#1 and solution \#2 immediately following. Solution \#1 was composed of humidity condensate and urine, including flush water and pretreatment chemicals. Solution \#2 was composed of hygiene water, humidity condensate, and urine, including flush water and pretreatment chemicals. During the testing, the operational parameters of the WFRD were recorded and samples of the feed, brine, and product were collected and analyzed. The steady-state results of processing 414L of feed solution \#1 and 1283L of feed solution \#2 demonstrated that running the WFRD at a brine temperature of $50^{\circ} \mathrm{C}$ gave an average production rate of 16.7 $\mathrm{L} / \mathrm{hr}$. The specific energy consumption was $80.5 \mathrm{~W}-\mathrm{hr} / \mathrm{L}$. Data Analysis shows that the water recovery rates were $94 \%$ and $91 \%$, respectively. The total mass of the WFRD as delivered to MSFC was $300 \mathrm{Kg}$. The volume of the tests stand rack was $1 \mathrm{~m}$ width $\times 0.7 \mathrm{~m}$ depth $\times 1.9 \mathrm{~m}$ height or $1.5 \mathrm{~m}^{3}$ of which about half of the total volume is occupied by equipment. Chemical analysis of the distillate showed an average TOC of $20 \mathrm{ppm}$, a $\mathrm{pH}$ of 3.5, and a conductivity of $98 \mu \mathrm{mho} / \mathrm{cm}$. The conductivity of the distillate, compared to the feed, decreased by $98.9 \%$., the total ion concentration decreased by $99.6 \%$, the total organics decreased $98.6 \%$, and the metals were at or below detection limits.

\section{Nomenclature}

$\begin{array}{lll}\mathrm{ARC} & = & \text { Ames Research Center } \\ { }^{\circ} \mathrm{C} & = & \text { degrees Centigrade } \\ \mathrm{CDS} & = & \text { Cascade Distillation System } \\ \mathrm{ECLS} & = & \text { Environmental Controls and Life Support } \\ \mathrm{ELS} & = & \text { Exploration Life Support } \\ \text { ELSDDST } & = & \text { ELS Distillation Down-Select Test }\end{array}$

${ }^{1}$ Job Title, Department, Address/Mail Stop, and AIAA Member Grade for third author.

2 Job Title, Department, Address/Mail Stop, and AIAA Member Grade for third author.

${ }^{3}$ Job Title, Department, Address/Mail Stop, and AIAA Member Grade for third author.

${ }^{4}$ Job Title, Department, Address/Mail Stop, and AIAA Member Grade for third author. 


\begin{tabular}{|c|c|c|}
\hline gm & $=$ & grams \\
\hline $\mathrm{Kg}$ & $=$ & kilograms \\
\hline $\mathrm{kJ} / \mathrm{m}^{30} \mathrm{C} \mathrm{hr}$ & $=$ & kilojelous per cubic meter per degree centigrade per hour \\
\hline JSC & $=$ & Johnson Space Center \\
\hline $\mathrm{L}$ & $=$ & Liter \\
\hline $\mathrm{L} / \mathrm{hr}$ & $=$ & Liters per hour \\
\hline $\mathrm{lb}$ & $=$ & pounds \\
\hline $\mathrm{m}$ & $=$ & meters \\
\hline $\mathrm{m}^{3}$ & $=$ & cubic meters \\
\hline $\mathrm{ml}$ & $=$ & milliliters \\
\hline$\mu \mathrm{mho} / \mathrm{cm}$ & $=$ & reciprocal ohms per centimeter \\
\hline ppm & $=$ & parts per million \\
\hline MSFC & $=$ & Marshall Space Flight Center \\
\hline NASA & $=$ & National Aeronautics and Space Administration \\
\hline $\mathrm{pH}$ & $=$ & the negative log of the hydrogen ion activity \\
\hline REMS & $=$ & Regenerative ECLS module simulator \\
\hline std. dev. & $=$ & standard deviation \\
\hline TDS & $=$ & Total Dissolved Solids \\
\hline TIC & $=$ & Total Inorganic Solids \\
\hline TOC & $=$ & Total Organic Solids \\
\hline TSS & $=$ & Total Suspended Solids \\
\hline the $\mathrm{VCD}$ & $=$ & the VCD system being developed by MSFC \\
\hline $\mathrm{VCD}$ & $=$ & Vapor Compression Distillation \\
\hline VPCAR & $=$ & Vapor Phase Catalytic Ammonia Removal \\
\hline WFRD & $=$ & Wiped Film Rotating Disk \\
\hline W & $=$ & watts \\
\hline $\mathrm{W}-\mathrm{hr} / \mathrm{L}$ & $=$ & specific energy, watt - hours per liter \\
\hline wt. & $=$ & weight \\
\hline
\end{tabular}




\section{Introduction}

This Wiped Film Rotating Disc (WFRD) was assembled, modified, and upgraded as part of a 9 month program to support the ELS Distillation Down-Select Test (ELSDDST). The Wiped Film Rotating Disc WFRD test hardware delivered to MSFC was a refurbished older unit that was constructed in the early 1990's as a component part of the original Vapor Phase Catalytic Ammonia Removal (VPCAR) ${ }^{1-2}$ system. The original VPCAR system had been dissembled and surplused in the late 1990's during the development of the $2^{\text {nd }}$ generation VPCAR system and is now being reassembled (minus the oxidative reactors) as the WFRD ${ }^{3-5}$.

The stand alone WFRD is configured as a vapor compression distillation system. A WFRD system is a particularly energy efficient water distillation process. A flow diagram of the WFRD system is provided in Figure 1. The WFRD process derives its efficiency through the recycling of the latent heat of evaporation. In the WFRD cycle, a waste stream is introduced into the WFRD evaporator where energy is transferred to the wastewater feed causing the evaporation of a portion of it. This vapor is then compressed to increase its saturation temperature and condensed on a common condensation/evaporation surface. The liberated latent heat of condensation is then transferred through the heat transfer surface and used as the energy source for further evaporation of the feed. The net energy required for the process is only that which is needed to drive the compressor, operate the liquid pumps and any other associated rotating equipment, and make up for any thermodynamic losses, i.e. heat loss to the environment and inherent thermodynamic irreversibility.

Figure 2 shows the complete assembly of the WFRD test stand that was tested at MSFC. This system was constructed specifically for the ELSDDST. In the past, the WFRD has been developed by NASA as a component of the VPCAR technology.

\section{Methodology}

The testing methodology for the ELSDDST is documented in the "Exploration Life Support Water Recovery System Distillation Comparison Test Plan", JSC 47176, March 20, 2009. ${ }^{6}$ The primary objective of this test was to generate data establishing the performance of the WFRD technology in support of the ELDDST. This performance evaluation was accomplished by processing two waste water solutions that represent potential lunar base wastewater streams. Solution \#1 was a 30-day, 4-crew waste water stream composed of humidity condensate and

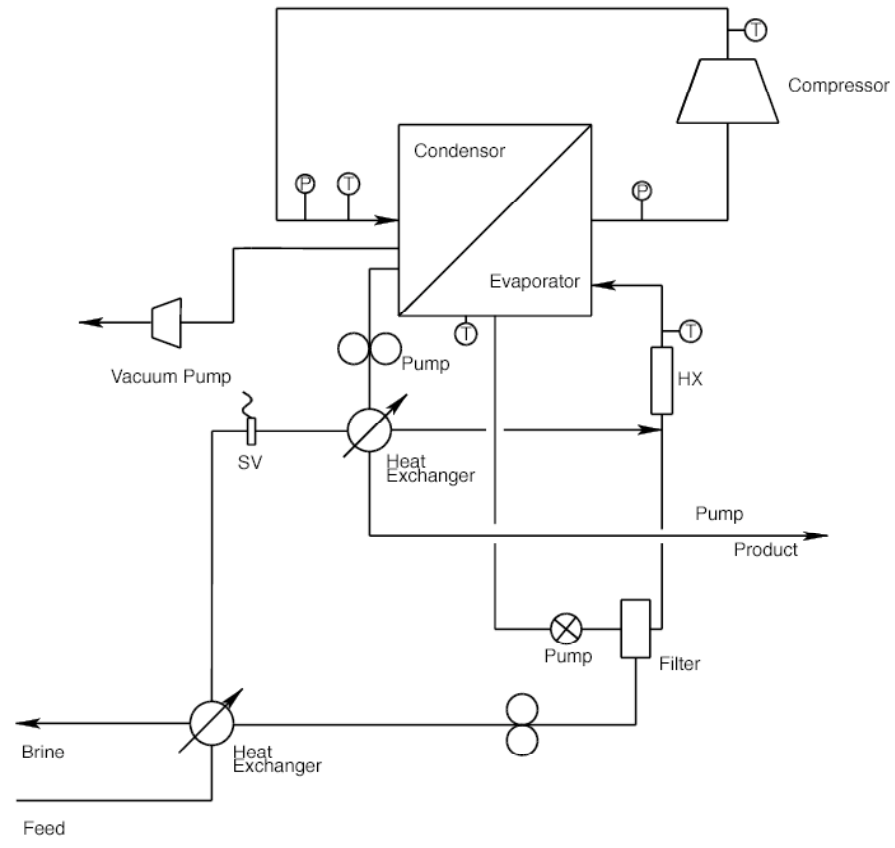

Figure 1. WFRD Flow Diagram

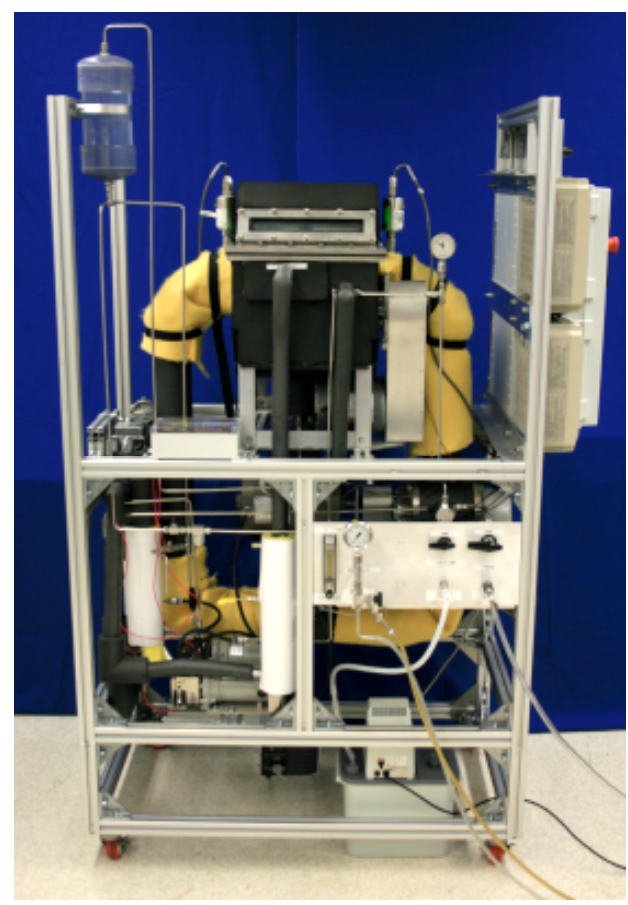

Figure 2. WFRD Test System as delivered to MSFC 
pretreated urine. Solution \#2 was a 30-day, 4-crew waste water stream composed of humidity condensate, pretreated urine, and hygiene waste waters.

The test objectives were as follows:

- $\quad$ Achieve a minimum of $93.5 \%$ water recovery of the Solution \#1.

- Achieve a minimum of $90 \%$ water recovery of the Solution \#2.

- Assess distillate quality and technology performance over the course of the test

Humidity condensate was generated to closely simulate the atmospheric contaminant load anticipated from a lunar surface mission. This was accomplished by collecting condensate from test subjects that exercise and performed hygiene activities in an enclosed facility, while also injecting contaminants to adequately represent the desired atmospheric quality. After the humidity condensate was collected, a pretreatment solution was added to maintain microbial control. This solution was comprised of $0.5 \mathrm{gm}$ of oxone and $0.11 \mathrm{gm}$ of sulfuric acid per liter of condensate. $^{6}$

Urine was collected from volunteers and each liter was pretreated with $5 \mathrm{gm}$ oxone, $2.3 \mathrm{gm}$ sulfuric acid, and $250 \mathrm{ml}$ of flush water. Hygiene was collected from volunteers using standard procedures (consistent with those implemented at Johnson Space Center for the evaluation of the Cascade Distillation System) to insure consistency. For Solution 1 (Table 1), hygiene activities were performed in the REMS (Regenerative ECLS module simulator) at MSFC, but the waste water was collected on hand towels and allowed to evaporate (to be collected with the humidity condensate). For Solution 2 (Table 2), waste water from the hygiene activities was collected for subsequent processing by the WFRD.

\section{Results and Discussion}

Nominally the WFRD was operated at the minimum water recovery ratio (93.5\% and $90.0 \%$, respectively) for the duration of the testing with the exception of the initial startup of the first run where brine was not removed in order to quickly bring the brine to the appropriate water recovery concentration. A brine bleed was then taken for the duration of the run. The average feed flow into the WFRD equals the average distillate and brine flows out. The WFRD does not use a replaceable brine filter tank such as the ones used by the VCD and CDS use and thus has no regular re-supply requirements.

Vacuum was provided with a water aspirator pump maintained at nominally at $9^{\circ} \mathrm{C}$ with the WFRD operated at a steady-state heater temperature of $50^{\circ} \mathrm{C}$. The aspirator pump was used to collect the liquid from the vacuum vent.

Treatment of each solution was analyzed and the results evaluated to ascertain the WFRD's performance during full-run, steady-state, and startup conditions.

\section{A. DATA SELECTION}

Data was analyzed for the start-up, steady-state, and full-run values.

\section{Determination of Steady-State Data}

Steady state was defined as operation after system temperatures stabilized. A heater in the brine recirculation loop is used to control the temperature of the evaporating feed. Although the WFRD was operated at a steady-state heater temperature of $50^{\circ} \mathrm{C}$, the steady-state brine temperature fluctuated between 52 and $53^{\circ} \mathrm{C}$ for Solution \#1. This discrepancy could be due to thermocouple inaccuracies or the normal mechanically generated self-heating of the WFRD. Only data collected after the brine temperature exceeded 52 degree $\mathrm{C}$ were kept for analysis as steady state, and the steady-state daily run was considered over when the production rate dropped below the steady-state value. 
For Solution \#2, the steady-state brine temperature fluctuated between 51.5 and $52.5^{\circ} \mathrm{C}$ and thus only data collected after the brine temperature exceeded $51.5^{\circ} \mathrm{C}$ were kept for analysis as steady state, and the steady-state daily run was considered over when the production rate dropped below the steady-state value.

Table 1. WFRD Daily Wastewater Generation for Solution \#1

\begin{tabular}{|l|l|l|}
\hline \multicolumn{1}{|c|}{ Wastewater } & \multicolumn{1}{|c|}{ Water Quantity } & \multicolumn{1}{|c|}{$\begin{array}{c}\text { Cleansing } \\
\text { Agent }\end{array}$} \\
\hline $\begin{array}{l}\text { Humidity } \\
\text { Condensate }\end{array}$ & $\begin{array}{l}15.6 \mathrm{~kg} / \text { day }(34.3 \\
\mathrm{lb} / \text { day })\end{array}$ & None \\
\hline Handwash & $\begin{array}{l}16 \text { per day, 55 } \\
\mathrm{ml} / \text { handwash }\end{array}$ & Water \\
\hline Full Body Wash & $\begin{array}{l}2 \text { per day, 55 } \\
\mathrm{ml} / \text { wash }\end{array}$ & Water \\
\hline Wet Shave & $\begin{array}{l}1 \text { per day, 55 } \\
\mathrm{ml} / \mathrm{shave}\end{array}$ & $\begin{array}{l}\text { Neutrogena } \\
\text { Shave Cream }\end{array}$ \\
\hline Oral Hygiene & $\begin{array}{l}4 \text { toothbrush/day, } \\
28 \mathrm{ml} / \text { activity }\end{array}$ & $\begin{array}{l}\text { Arm \& } \\
\text { Hammer } \\
\text { Dental Care }\end{array}$ \\
\hline $\begin{array}{l}\text { Pretreated Urine } \\
+ \text { Flush water }\end{array}$ & $\begin{array}{l}12.0 \mathrm{~kg} / \text { day }(13.2 \\
\mathrm{lb} / \text { day })\end{array}$ & N/A \\
\hline
\end{tabular}

\section{Determination of Startup Data}

The startup data included all data from when the system was started and the brine temperature began increasing for the daily run up until the steady-state cut-off temperature $\left(52.0\right.$ and $51.5^{\circ} \mathrm{C}$, respectively) was achieved.

\section{Determination of Full-Run Data}

The full run data included all the startup and steady-state data.

\section{B. SOLUTION \#1 DATA ANALYSIS}

Table 3 shows a summary of the solution \#1 data analysis.

\section{Steady-State Data}


Operating the brine loop heater at $50^{\circ} \mathrm{C}$ gave a steady-state brine temperature of about $52.7^{\circ} \mathrm{C}$. This temperature gave an average production rate of $16.6 \mathrm{~L} / \mathrm{hr}$ with a specific energy consumption of $80.1 \mathrm{~W}-\mathrm{hr} / \mathrm{L}$. The average power requirement was $1327 \mathrm{~W}$ with a standard deviation of $65 \mathrm{~W}$ at a pressure ratio of 1.27. The highest instantaneous peak power was $1551 \mathrm{~W}$. The percent water recovery rate was $94.4 \%+/-0.6 \%$.

\section{Startup Data}

The average startup time was 82 minutes. For this period, the production rate goes from $0 \mathrm{~L} / \mathrm{hr}$ to the steadystate value with an average production rate of $9.2 \mathrm{~L} / \mathrm{hr}$ with an average specific energy consumption of $111.1 \mathrm{~W}$ $\mathrm{hr} / \mathrm{L}$. The average power requirement was $1025 \mathrm{~W}$.

3.

Full-Run Data

The full run for each day took 5 to 5.5 hours. This timing was set by the operators and conformed to an $8 \mathrm{hr}$ work day. For this period, there was a start up period of approximately 82 minutes followed by 3.5 to 4 hours of operations at steady-state. This resulted in an average daily production rate of $14.2 \mathrm{~L} / \mathrm{hr}$ with an average specific energy consumption of $85.3 \mathrm{~W}-\mathrm{hr} / \mathrm{L}$ at a pressure ratio of 1.25 . Thus, the startup costs only increased the average specific energy consumption by $5 \mathrm{~W}-\mathrm{hr} / \mathrm{L}$. The average power requirement for a day's run was $1214 \mathrm{~W}$. The percent water recovery rate was $91.9+/-1.5 \%$. At the end of each day's run the system was left containing the brine from the previous run.

\section{SOLUTION \#2 DATA ANALYSIS}

Table 3 shows a summary of the solution $\# 2$ data analysis.

\section{Steady-State Data}

Operating the brine loop heater at $50^{\circ} \mathrm{C}$ gave a steady-state brine temperature of about $52.2^{\circ} \mathrm{C}$. This temperature gave a production rate of $16.7 \mathrm{~L} / \mathrm{hr}$ with a specific energy consumption of $80.6 \mathrm{~W}-\mathrm{hr} / \mathrm{L}$. The average power requirement was $1344 \mathrm{~W}$ with a standard deviation of $207 \mathrm{~W}$ at a pressure ratio of 1.33 . The highest instantaneous peak power was $1743 \mathrm{~W}$. The percent water recovery rate was $90.7 \%+/-0.4 \%$.

\section{Startup Data}

The average startup time was 80 minutes. For this period, the production rate goes from $0 \mathrm{~L} / \mathrm{hr}$ to the steadystate value with an average production rate of $9.2 \mathrm{~L} / \mathrm{hr}$ with an average specific energy consumption of $116.2 \mathrm{~W}$ $\mathrm{hr} / \mathrm{L}$. The average power requirement was $1066 \mathrm{~W}$.

3.

Full-Run Data

The full run for each day took 5 to 5.5 hours. For this period, there was a start up period of approximately 80 minutes followed by 3.5 to 4 hours of operations at steady-state. This resulted in an average daily production rate of $14.7 \mathrm{~L} / \mathrm{hr}$ with an average specific energy consumption of $86.4 \mathrm{~W}-\mathrm{hr} / \mathrm{L}$ at a pressure ratio of 1.32 . Thus the startup costs increased the average daily specific energy consumption by $6 \mathrm{~W}-\mathrm{hr} / \mathrm{L}$. The average power requirement for a day's run was $1267 \mathrm{~W}$. The percent water recovery rate was $89.9+/-0.2 \%$. 
Table 3. Summary of WFRD operational data.

Full-run

Steady-state

\begin{tabular}{|c|c|c|c|c|}
\hline & & & & \multirow[b]{2}{*}{ Solution \#2 } \\
\hline & \multicolumn{2}{|c|}{$\begin{array}{ll}\text { Solution \#1 } & \text { Solution \#2 }\end{array}$} & Solution \#1 & \\
\hline Temperature & $50 \mathrm{C}$ & $50 \mathrm{C}$ & $50 \mathrm{C}$ & $50 \mathrm{C}$ \\
\hline Total Power & $1214+/-289 W$ & $1267+/-269 \mathrm{~W}$ & $1327+/-65 \mathrm{~W}$ & $1344+/-207 \mathrm{~W}$ \\
\hline Production Rate $^{a}$ & $14.2+/-4.8 \mathrm{~L} / \mathrm{hr}$ & $14.7+/-4.7 \mathrm{~L} / \mathrm{hr}$ & $16.6+/-1.6 \mathrm{~L} / \mathrm{hr}$ & $16.7+/-2.6 \mathrm{~L} / \mathrm{hr}$ \\
\hline Specific Energy & $85.3 \mathrm{~W}-\mathrm{hr} / \mathrm{L}$ & 86.4 W-hr/L & $80.1 \mathrm{~W}-\mathrm{hr} / \mathrm{L}$ & $80.8 \mathrm{~W}-\mathrm{hr} / \mathrm{L}$ \\
\hline Recovery Ratio $^{b}$ & $91.9+/-1.5 \%$ & $89.9+/-0.2 \%$ & $94.6+/-0.6 \%$ & $90.7+/-0.4 \%$ \\
\hline Startup Time & $82 \mathrm{~min}$ & $80 \mathrm{~min}$ & $\mathrm{~N} / \mathrm{A}$ & N/A \\
\hline
\end{tabular}

D.

CHEMICAL ANALYSIS

Feed, brine, and distillate samples were collected and sent to an independent laboratory for chemical analysis. No more than one set of samples were collected per day, and normally they were collected every second day. This analysis included the TOC, TIC, $\mathrm{pH}$, conductivity, turbidity, TSS, TDS, selected anions and cations, selected metals, and analysis for alcohols, aldehydes, organic acids, glycols, and ketones. This data is summarized in Table 4. Table 4 contains a statistical compilation of data for both feed solutions \#1 and Solution \#2.

The chemical analysis of the distillate produced the following major results: an average TOC of 20ppm, $\mathrm{pH}$ of 3.5 , and conductivity of $98 \mu \mathrm{mho} / \mathrm{cm}$. The conductivity of the distillate compared to the feed decreased by $98.9 \%$, the total ion concentration decreased by $99.6 \%$, the total organics decreased by $98.6 \%$, and the metals analysis was mostly "below detection limit". 
Table 4. Summary of chemical analysis - a compilation of data from all solutions

\begin{tabular}{|c|c|c|c|c|c|c|c|}
\hline & & & & & Dis & late & \\
\hline & Average & Std. Dev. & Average & Std. Dev. & Average & Std. Dev. & Removal \\
\hline CHEMICAL ANALYSIS & & & & & & & \\
\hline Total Particles, ppm & 17509.4 & & & & 180.026 & & $>99$ \\
\hline $\mathrm{pH}$ & 2.31 & 0.02 & 1.83 & 0.1 & 3.5 & 0.19 & \\
\hline Surface Tension, dyn/cm & 46.57 & 9.06 & 32.94 & 9.25 & 59.33 & 20.17 & \\
\hline TSS, ppm & 17.14 & 11.6 & 334.3 & 152.58 & & & \\
\hline TDS, ppm & 8931.43 & 7989.05 & 60360 & 48209.74 & & & \\
\hline Turbidity, NTU & 10.95 & 5.55 & 453.7 & 367.93 & & & \\
\hline TOC, ppm & 1367.98 & 563.95 & 10720 & 9941.31 & 20.03 & 4.26 & 98.5 \\
\hline TIC, ppm & 12.91 & 3.77 & 8.56 & 4.81 & BDL & & $>96$ \\
\hline Conductivity, $\mu \mathrm{mho} / \mathrm{cm}$ & 8963.1 & 905.01 & 42376.6 & 23472.9 & 97.89 & 36.44 & 98.9 \\
\hline Total Ions, ppm & 3879.1 & & & & 16.97 & & 99.6 \\
\hline Total Organics, ppm & 3284.7 & & & & 44.92 & & 98.6 \\
\hline Total Metals, ppm & 1.6213 & & & & 0.2163 & & 86.7 \\
\hline
\end{tabular}

1.

Ion Analysis

A number of ionic species were selected for analysis. They included $\mathrm{Na}^{+}, \mathrm{K}^{+}, \mathrm{Mg}^{2+}, \mathrm{Ca}^{2+}, \mathrm{Cl}^{-}, \mathrm{NO}^{3-}, \mathrm{PO}_{4}{ }^{3-}$, and $\mathrm{SO}_{4}{ }^{2-}$. Data analysis for Solution $\# 1$ and Solution $\# 2$ were grouped together since there was a limited number of data points for the analysis of many of the ions.

Most of the ions were removed at a level that was greater than $99 \%$ with the only exceptions being Ammonium (97.8\%) and Chloride (98.9\%). The ammonium removal is affected by the ability of ammonia to volatilize and move through the gas phase into the distillate. Total ions removed was greater than $99 \%$ 
Table 5. Chemical Analysis for Ions

\begin{tabular}{|c|c|c|c|c|c|c|c|}
\hline & \multicolumn{2}{|c|}{ Feed } & \multicolumn{2}{|c|}{ Brine } & \multicolumn{2}{|c|}{ Distillate } & \multirow{2}{*}{$\begin{array}{l}\% \\
\text { Removal }\end{array}$} \\
\hline & Average & Std. Dev. & Average & Std. Dev. & Average & Std. Dev. & \\
\hline TOTAL IONS & 3879.1 & & & & 16.97 & & 99.6 \\
\hline Sodium $(\mathrm{Na}+), \mathrm{ppm}$ & 474.05 & 83.86 & 4241.2 & 3894.98 & 0.73 & 0.16 & 99.8 \\
\hline Potassium $(\mathrm{K}+), \mathrm{ppm}$ & 101.46 & 10.24 & 930 & 614.09 & BDL & N/A & $>99$ \\
\hline Ammonium $(\mathrm{NH} 4+)$, ppm & 65.7 & 9.75 & 175.33 & 5.51 & 1.47 & 0.55 & 97.8 \\
\hline Magnesium $(\mathrm{Mg} 2+), \mathrm{ppm}$ & BDL & & 201.33 & 118.85 & BDL & & \\
\hline Calcium $(\mathrm{Ca} 2+), \mathrm{ppm}$ & BDL & & 326.8 & 123.4 & BDL & & \\
\hline Chloride (Cl-), ppm & 807.79 & 216.17 & 7224.2 & 8005.32 & 8.55 & 3.86 & 98.9 \\
\hline Nitrate (NO3-), ppm & 75.87 & 13.78 & 572.67 & 374.01 & 0.78 & 0.37 & 99 \\
\hline Phosphate (PO43-), ppm & 482.69 & 162.62 & 926 & 187.95 & 2 & 0.2 & 99.6 \\
\hline Sulfate (SO42-), ppm & 1871.53 & 282.28 & 17284 & 14959.34 & 3.43 & 0.92 & 99.8 \\
\hline
\end{tabular}

2.

Organic Analysis

The WFRD removed $98.7 \%$ of the total organic concentration. The major constituent was urea, and it was removed at $99.8 \%$. The reason for the difference is because of the preferential volatilization of several of the more volatile components. Organics such as methanol, ethanol, formic acid and acetic acid all have boiling points close to water and are thus transferred to the distillate in trace quantities through the vapor phase. The average product TOC is $20 \mathrm{ppm}$. The distillate's TOC for Solution \#1 was $25.5 \mathrm{ppm}$ while the distillate's TOC for Solution \#2 was $17.9 \mathrm{ppm}$. 
Table 6. Chemical Analysis for Organics

\begin{tabular}{|c|c|c|c|c|c|c|c|}
\hline \multirow[b]{3}{*}{ TOTAL ORGANICS } & \multicolumn{2}{|l|}{ Feed } & \multicolumn{2}{|l|}{ Brine } & \multicolumn{2}{|l|}{ Distillate } & \multirow{2}{*}{$\begin{array}{l}\% \\
\text { Removal }\end{array}$} \\
\hline & Average & Std. Dev. & Average & Std. Dev. & Average & Std. Dev. & \\
\hline & $\overline{3284.7}$ & & & & 42.03 & & 98.7 \\
\hline Urea, ppm & 3233.33 & 372.27 & & & 5.4 & 1.4 & 99.8 \\
\hline Methanol & 1.59 & 0.34 & & & 1.7 & 0.44 & -7.2 \\
\hline Ethanol & 23.9 & 6.38 & & & 13.12 & 12.41 & 45.1 \\
\hline Other alcohols & 1.59 & 0.34 & & & 2.45 & 0.88 & -54.5 \\
\hline Formaldehydes & 0.17 & 0.04 & & & 0.31 & 0.27 & -80.3 \\
\hline Other Aldehydes & 0.17 & 0.04 & & & 0.31 & 0.27 & -80.3 \\
\hline Ethylene glycol & 3.25 & 1.98 & & & 1.25 & 0.06 & 61.7 \\
\hline Other Glycols & 8.65 & 3.57 & & & 9.33 & 6.99 & -7.9 \\
\hline Formic Acid, ppm & 5.27 & 0.58 & & & 3.89 & 2.11 & 26.1 \\
\hline Acetic Acid, ppm & $\mathrm{BDL}$ & 0 & & & 3.33 & 1.16 & \\
\hline Other organic Acids & 4.33 & 0.5 & & & 0.44 & 0.36 & 90.0 \\
\hline Acetone, ppm & 0.62 & 0.1 & & & 0.2 & 0.07 & 68.1 \\
\hline Other ketones & 1.82 & 0.89 & & & 0.29 & 0.25 & 83.8 \\
\hline
\end{tabular}

3.

Metal Analysis

The metals analyzed can be divided into 3 categories: WFRD metals, BDL (below detectable limits) uncommon metals, and uncommon metals.

The WFRD metals are the metals making up the materials of construction of the WFRD which is primarily stainless steel ( $\mathrm{Fe}, \mathrm{Ni}, \mathrm{Mg}$, and $\mathrm{Cr}$ ) and copper crush gaskets $(\mathrm{Cu})$. These metals are present in the feed in relatively low concentrations but are also present in the brine in much higher concentrations than can be attributed to just the concentration effects due to operation at high water recovery rates. For example, the iron level increases 600 times from the feed to the brine. The high level of these metals in the brine is likely the result of corrosion of the internal stainless steel components of the WFRD. This was expected and is the result of the pretreatment used which reduced the $\mathrm{pH}$ of the feed to about 2. WFRD metals are also found in the product due to the low $\mathrm{pH}$ of the distillate. To prevent this corrosion will require constructing the WFRD out of a different material such as titanium. 
The BDL uncommon metals are $\mathrm{Ar}, \mathrm{Ba}, \mathrm{Cd}, \mathrm{Pb}, \mathrm{Hg}$, and $\mathrm{Se}$. All of the BDL uncommon metals are reported as below detection limits in the distillate although three of these metals did have detectible concentrations in some of the feed samples.

The third group, the uncommon metals (such as Ag and Zn), are not found in the construction of the WFRD and have detectable quantities in both the feed and distillate. $\mathrm{Ag}$ and $\mathrm{Zn}$ have a percent removal of $96 \%$ to $97 \%$, respectively.

It is therefore proposed that the distillation process removes $>95 \%$ of the metals from the feed, with some of the WFRD metals being re-dissolved into the distillate

Table 7. Chemical Analysis for Metals

\begin{tabular}{|c|c|c|c|c|c|c|c|}
\hline & \multicolumn{2}{|c|}{ Feed } & \multicolumn{2}{|c|}{ Brine } & \multicolumn{2}{|c|}{ Distillate } & \multirow{2}{*}{$\begin{array}{l}\text { \% } \\
\text { Removal }\end{array}$} \\
\hline & Average & Std. Dev. & Average & Std. Dev. & Average & Std. Dev. & \\
\hline TOTAL METALS & 1.6213 & & & & 0.2163 & & $>86.7$ \\
\hline \multicolumn{8}{|l|}{ WFRD Metals } \\
\hline $\mathrm{Cr}$ & 0.0154 & 0.0067 & 9.1936 & 4.8423 & 0.0285 & 0.02 & -85.7 \\
\hline $\mathrm{Cu}$ & 0.0332 & 0.0042 & 1.5002 & 0.326 & 0.0474 & 0.0183 & -42.8 \\
\hline $\mathrm{Fe}$ & 0.054 & 0.028 & 30.468 & 7.4832 & 0.0702 & 0.0683 & -30.2 \\
\hline $\mathrm{Mn}$ & 0.0262 & 0.0197 & 3.4532 & 3.2383 & 0.011 & 0.0124 & 57.9 \\
\hline $\mathrm{Ni}$ & 0.0225 & 0.0055 & 1.5157 & 1.8175 & 0.0134 & 0.0096 & 40.4 \\
\hline \multicolumn{8}{|c|}{ BDL uncommon metals } \\
\hline As & 0.0087 & 0.0039 & 0.0383 & 0.0214 & BDL & & $>94$ \\
\hline $\mathrm{Ba}$ & 0.006 & BDL & 0.1124 & 0.0522 & BDL & & $>91$ \\
\hline $\mathrm{Cd}$ & BDL & & 0.025 & 0.0184 & BDL & & \\
\hline $\mathrm{Pb}$ & $\mathrm{BDL}$ & & 0.0445 & 0.0106 & BDL & & \\
\hline $\mathrm{Hg}$ & $\mathrm{BDL}$ & & 1.1016 & 0.6485 & BDL & & \\
\hline $\mathrm{Se}$ & 0.1695 & 0.0163 & 0.4669 & 0.543 & BDL & & $>94$ \\
\hline
\end{tabular}

uncommon metals

$\begin{array}{llllllll}\mathrm{Ag} & 0.8399 & 0.1622 & 3.3664 & 3.7885 & 0.0342 & 0.0341 & \mathbf{9 5 . 9} \\ \mathrm{Zn} & 0.446 & 0.0382 & 1.4873 & 1.1309 & 0.0115 & 0.0007 & \mathbf{9 7 . 4}\end{array}$


E.

The average production rate for both solutions is $16.7 \mathrm{~L} / \mathrm{hr}$ at steady state and $14.6 \mathrm{~L} / \mathrm{hr}$ for a daily 5 hour run. Figure 3 shows that production rate is proportional to the brine temperature at which the WFRD is run. As the brine temperature increases at the beginning of each days run, so does the production rate. As the temperature drifts up and down at the steady-state condition, so does the production rate.

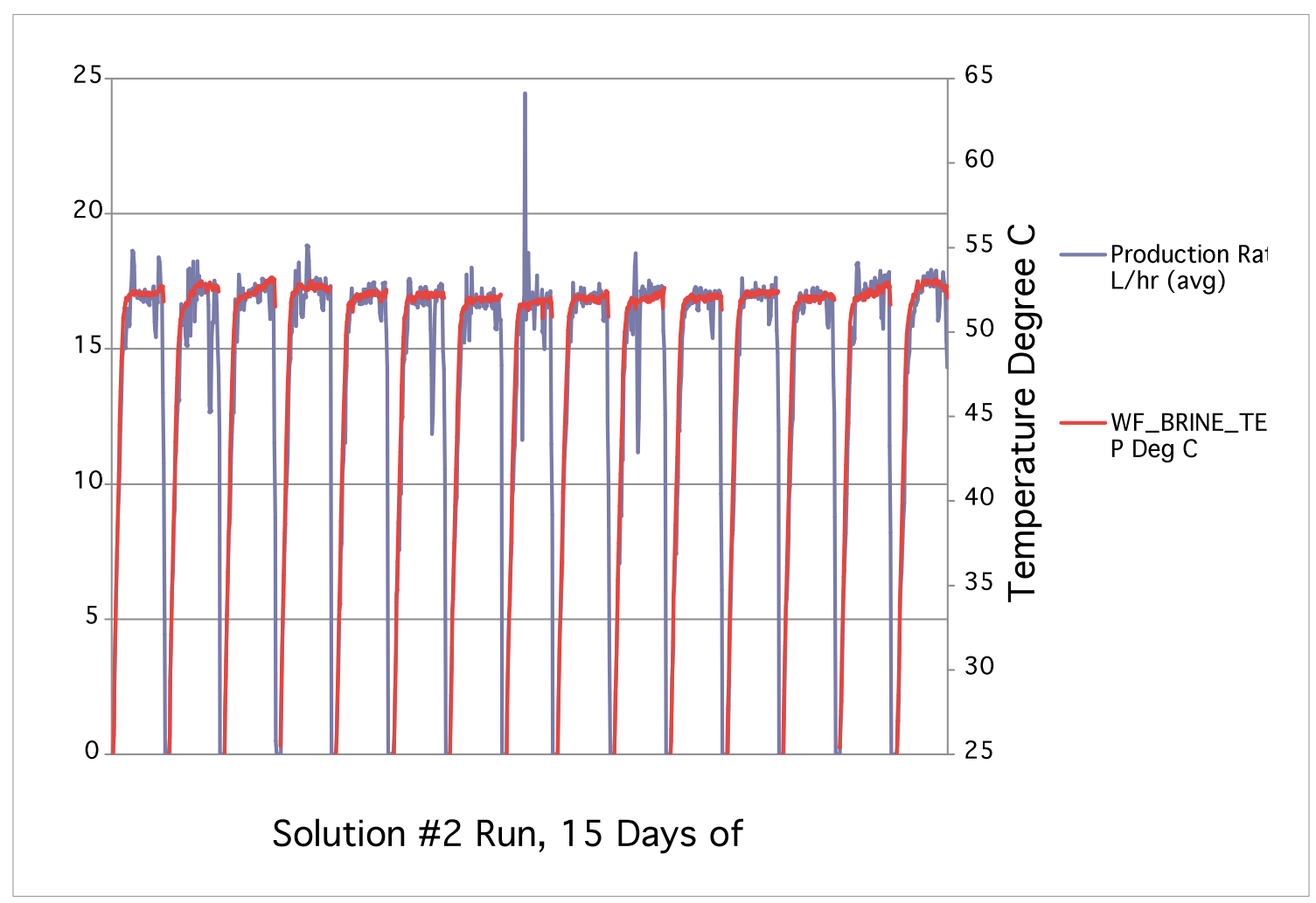

Figure 3. Plot showing the correlation between the brine temperature and the production rate of the WFRD. The noise within the production rate was smoothed by averaging the data point with the data that followed and preceded it, i.e., the 15 minute average. 
The total mass of the WFRD as delivered to MSFC was $300 \mathrm{~kg}$. This includes the entire working systems hardware weight; the WFRD chamber, the pumps, the tubing, the control systems, the power analysis equipment, and the rack in which it is all mounted. The majority of the WFRD is built out of heavy stainless steel that is not optimized for weight. Notable exceptions are the rack which is aluminum and the compressor which is titanium. Table 8 provides a breakdown of all the component masses of the WFRD. A flight system would have to be made of titanium due to corrosion issues as noted in the metal analysis section above.

If titanium is used instead of stainless steel (40\% wt. reduction), and if the WFRD chamber was weight optimized (not built out of 1/2" thick stainless steel, an over designed safety feature), the weight of the WFRD could be reduced to by over $50 \%$.

Table 8. WFRD Component Mass (in kg)

\begin{tabular}{|c|c|c|c|c|c|}
\hline Item & $\begin{array}{c}\text { Test Rig } \\
\text { Mass, Kg }\end{array}$ & $\begin{array}{c}\text { w/o } \\
\text { support } \\
\text { Mass, Kg }\end{array}$ & $\begin{array}{c}\text { as } \\
\text { titanium } \\
\text { Mass, } \mathbf{K g}\end{array}$ & $\begin{array}{c}\text { design } \\
\text { optimized } \\
\text { Mass, Kg }\end{array}$ & $\begin{array}{c}\text { w/o } \\
\text { motor } \\
\text { Mass, Kg }\end{array}$ \\
\hline WFRD Chamber & 64.68 & 64.68 & 36.87 & 18.43 & 18.43 \\
\hline WFRD Rotor & 9.29 & 9.29 & 5.30 & 5.30 & 5.30 \\
\hline 2 1/2' Piping & 22.75 & 22.75 & 12.97 & 4.28 & 4.28 \\
\hline Brine Loop Tubing & 2.20 & 2.20 & 1.25 & 0.63 & 0.63 \\
\hline Brine Loop Filter & 7.91 & 7.91 & 4.51 & 1.13 & 1.13 \\
\hline Misc Components & 2.88 & 2.88 & 1.64 & 1.64 & 1.64 \\
\hline Misc Tubing & 1.20 & 1.20 & 0.69 & 0.34 & 0.34 \\
\hline Motors and Pumps & 39.77 & 39.77 & 39.77 & 39.77 & \\
\hline Framing and Mounting & 56.37 & & & & \\
\hline Power and Control & 92.76 & & & & \\
\hline Total Mass & 300 & 151 & 103 & 72 & 32 \\
\hline
\end{tabular}

G.

OFF NOMINAL OPERATIONS

The WFRD ran reliably for the duration of the test with the exception of day 5 following a recirculation pump failure. This pump was removed and replaced and the run continued within the same day. Examination of the pump showed that it failed due to a defect in manufacturing.

On Day 13, there was a problem with the facility data analysis system that resulted in the system being shut down for a couple of hours.

For both of these issues, the non-steady-state data was removed from the analysis, and the rest of the data was analyzed normally. 
It was noted that the flow to several of the wiper blades slowly decreased during the test. (The wiper blades ensure that the feed is spread evenly and continuously across the disc and help ensure that solids do not build up on the disc.) This is a problem that had been observed earlier during testing prior to shipment to JSC. The wipers were adjusted prior to shipping to MSFC in an attempt to mitigate this issue. It is believed to be caused by the deformation of the wiper material and the resulting constriction of the fluid flow paths in the wipers.

H. PRECIPITATION IN WFRD CHAMBER

The WFRD was designed to run with some solids within the brine loop. The WFRD uses a wiped-film evaporator. This evaporator uses a wiper blade to add fluid feed and remove any solids that might build up on the evaporation surface. Our testing has shown that this wiper is effective against the build-up of most solids. The exception to this is scale forming solids such as calcium carbonate and calcium sulfate. These solids may not be removed by the wipers. The formation of scale solids typically limits the maximum water recovery ratio of the system for a given feed.

At the end of the testing of solution \#2 the WFRD Chamber was opened and the presence of solids was noted, see Figure 4. The circular stripes of white material shown in figure 4 are indicative of scale. However, it should be noted that prior to this inspection, the system was noted to be operating normally. Data recorded at the time indicated that production was unchanged. The power consumption for the last run did rise slightly at the end (see Fig. 5), and an increase in power consumption can be indicative of scale forming on the heat transfer surfaces.

A sample of the solid material was collected from each disk and was sent out for analysis. Energy dispersive Xray spectroscopy (EDS) analysis was taken for solids samples for each disk and from a single disk where visual inspection indicated differences in chemical makeup. Figure 6 and 7 present the results of this analysis. From Figure 6 it is clear that the yellowish/orange samples (from disk 1) and brown samples (from disk 4) are primarily organic solids and should not pose a problem. From Figure 7 it appears that likewise the yellowish/orange samples (from disk 1) and white samples (from disks 2 and 3) are not calcium scales because they have low levels of calcium. This would not be expected if they were a scale solid. This is true for all but the white fibers taken from disk 2 which are indicative of a calcium scale due to their high calcium levels. The existence of some calcium scale in disk 2 indicates that the system is operating right at the limit to water recovery ratio and that if it was exceeded would cause problematic scaling.

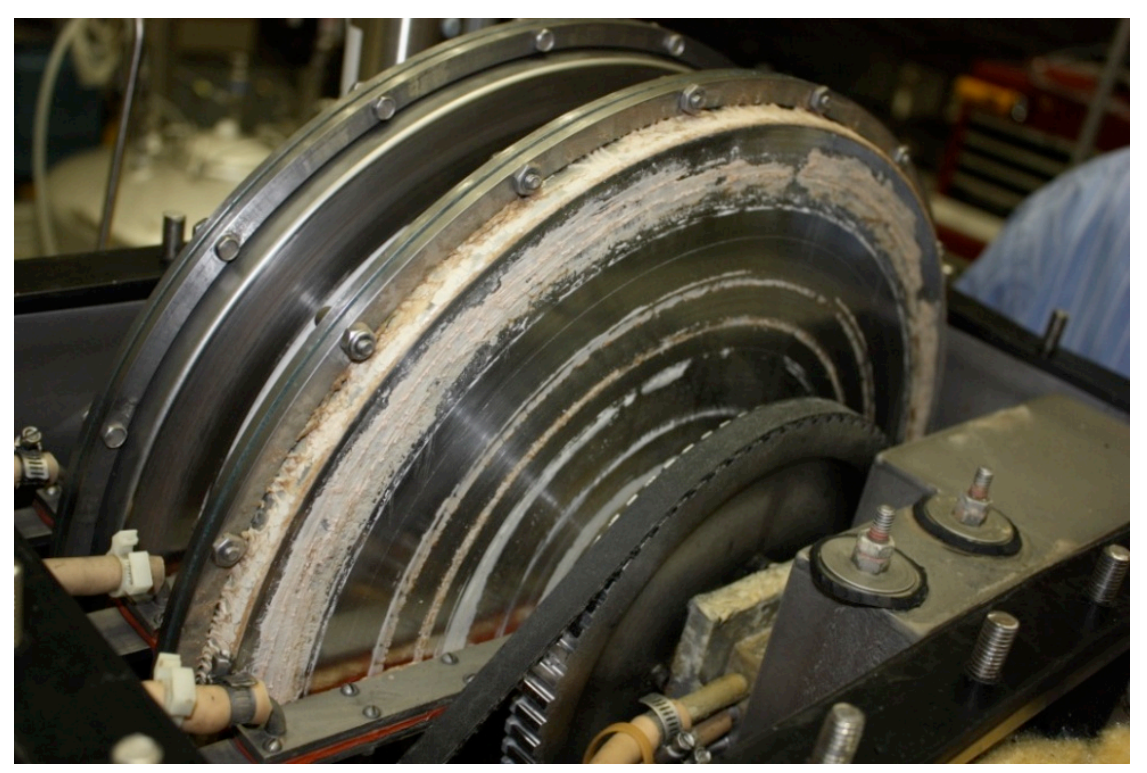

Figure 4. Precipitation of solids on disks at end of test. 



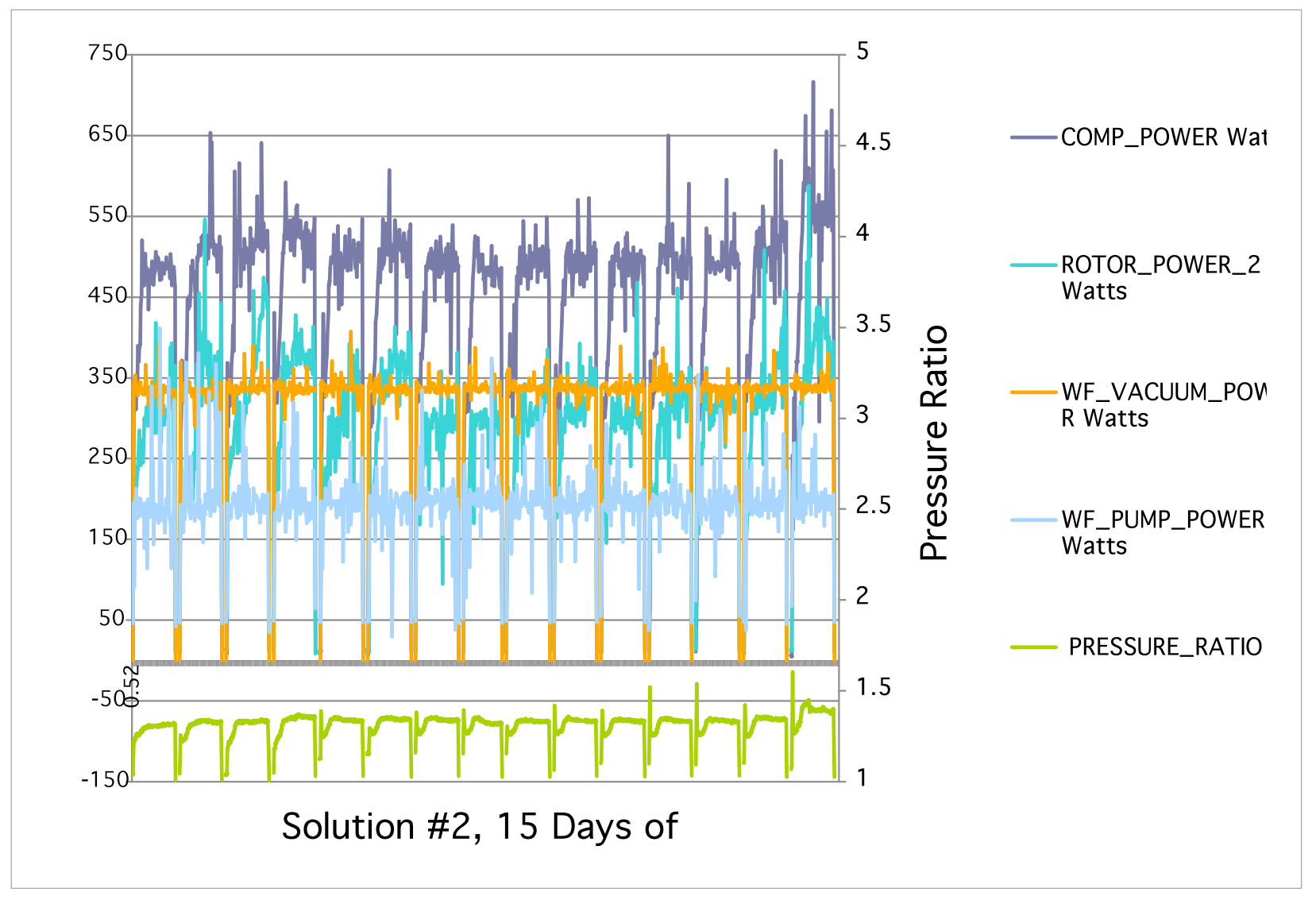

Figure 5. Power data for run with solution \#2. Note slight power increase in compressor and rotor power during last day of the test. Also notice the slight increase in pressure ratio during the last day of the test.

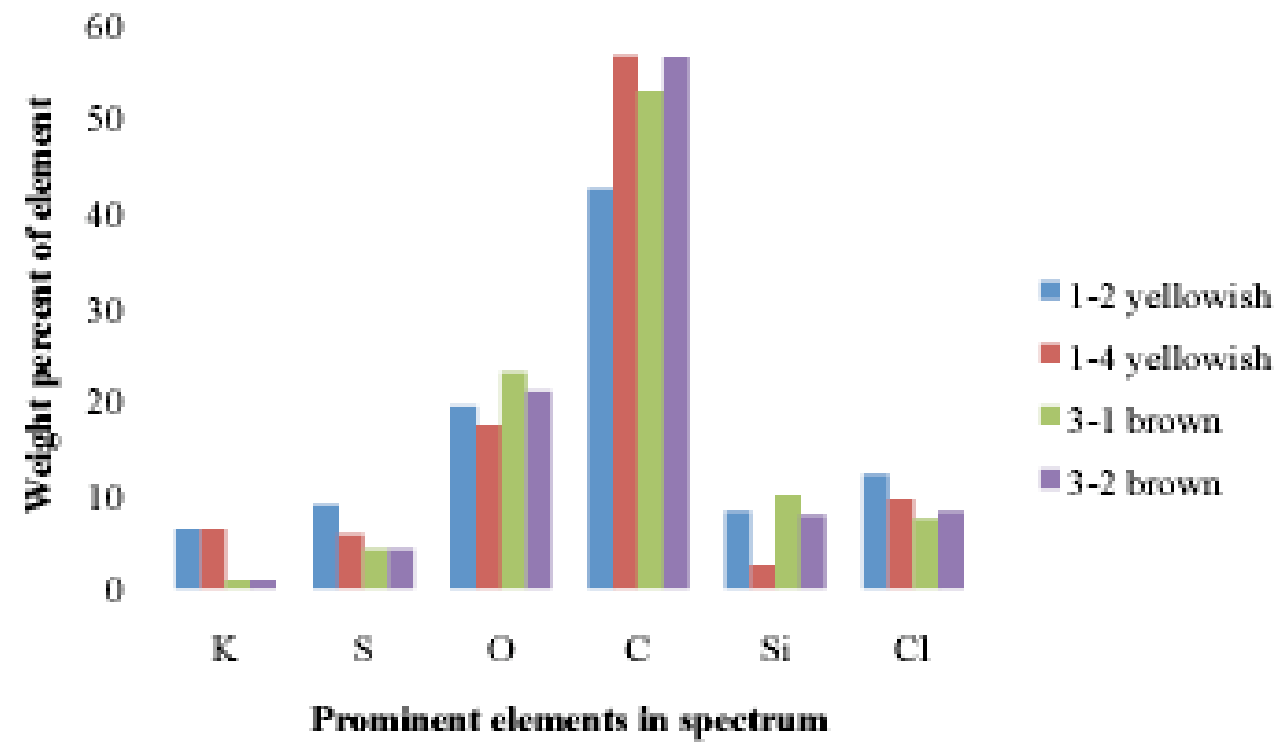

Figure 6. Correlation between yellowish/orange samples (from disk 1) and brown samples (disk 4) 


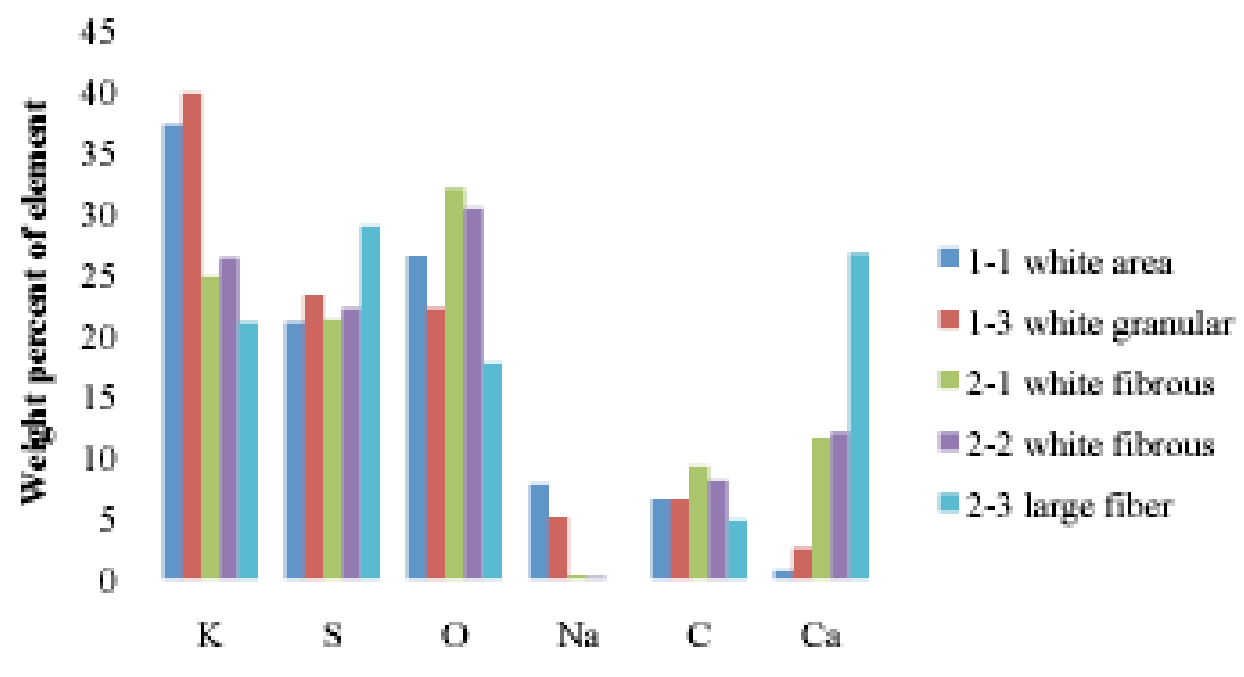

Prominent elements in EDS speetrum

Figure 7. Correlation between yellowish/orange samples (from disk 1) and white samples (disks 2 and 3)

\section{Conclusions}

Development and testing of the WFRD in support of the Exploration Life Support Distillation Down Select test has been successfully completed. The WFRD was constructed at Ames Research Center (ARC) and was tested at Marshal Space Flight Center (MSFC). The WFRD was delivered to MSFC in September 2009 with the beginning of testing Solution \#1 starting on Sept 15 and with Solution \#2 immediately following. During the testing, the operational conditions of the WFRD were recorded and samples of the feed, brine, and product were collected and analyzed.

Analysis of the data collected during the testing showed that running the WFRD at $50^{\circ} \mathrm{C}$ gave an average production rate of 16.6 and $16.7 \mathrm{~L} / \mathrm{hr}$, respectively, for the two solutions tested. The specific energy consumption was 80.1 and $80.6 \mathrm{~W}-\mathrm{hr} / \mathrm{L}$, respectively. Data Analysis for the steady-state operating condition shows that the water recovery rates were $94 \%$ and $91 \%$ respectively. When the full 5 hour daily run was analyzed, the specific energy consumption increased to $85 \mathrm{~W}-\mathrm{hr} / \mathrm{L}$, this value includes all startup power costs. The total mass of the WFRD as delivered to MSFC was $300 \mathrm{Kg}$. The volume was $1.5 \mathrm{~m}^{3}$ of which about half was occupied by equipment.

The chemical analysis of the distillate showed that the average TOC is $20 \mathrm{ppm}$, the $\mathrm{pH}$ is 3.5 , the conductivity decreased $98.9 \%$, the total ion concentration decreased by $99.6 \%$, the total organics decreased $98.6 \%$, and the metals analysis results where predominantly below detection limits.

\section{References}

\footnotetext{
${ }^{1}$ Tomes, K., Long, D., Carter, L., and Flynn, M., “Assessment of the Vapor Phase Catalytic Ammonia Removal (VPCAR) Technology at the MSFC ECLS Test Facility”, SAE Technical Papers Series No. 2007-01-3036, 37 ${ }^{\text {th }}$ International Conference on Environmental Systems, 2007.

${ }^{2}$ Delzeit, L. and Flynn, M., "Current and Planned Modifications to the Vapor Phase Catalytic Ammonia Removal (VPCAR) Technology in Response to the MSFC ECLS Long Duration Test Results”, SAE Technical Papers Series No. 2008-01-2141, 38 International Conference on Environmental Systems, San Francisco, Ca, June 2008.
} 
${ }^{3}$ Tleimat, B., "The Development of the Wiped-Film, Rotating-Disk Evaporator for the Reclamation of Water At Microgravity", SAE Technical Papers Series No. 2002-01-2397, 32th International Conference on Environmental Systems, San Antonio, TX, July 2002.

${ }^{4}$ Flynn, M., "The Development of the Vapor Phase Catalytic Ammonia Removal (VPCAR) Engineering Development Unit”, SAE Technical Papers Series No. 2004-01-2495, 34th International Conference on Environmental Systems, Colorado Springs, CO, 19-22 July 2004.

${ }^{5}$ Flynn, M., Tleimat, M., Nalette, T., and Quinn, R., "Performance Testing of the Vapor Phase Catalytic Ammonia Removal Engineering Development Unit”, SAE Technical Papers Series No. 2005-12-05, 34th International Conference on Environmental Systems, Colorado Springs, CO, 19-22 July 2004.

6“Exploration Life Support Water Recovery System Distillation Comparison Test Plan”, JSC 47176, March 20, 2009. 